\title{
Formation of the EU Development Index
}

\author{
Vladislavs Vesperis* \\ Crosssectoral coordination centre, LLU
}

\begin{abstract}
In the context of the global financial-economic crisis it becomes important to find a stronger base for assessment of the socio-economic development and, in particular, search for better indicators. Therefore, the hypothesis is set that it is necessary to develop the EU Development Index, which will provide better assessment of an on-going socio-economic change. The objective of the article is to describe the EU Development Index calculation results and compare them with the Human Development Index values for each Member state of the EU. Ranking list of the EU Member States according to the Human Development Index values did not change substantially, suggesting that the Human Development Index inadequately responds to key socioenvironmental changes that occurred during the global financial economic crisis. At the same time, a number of countries show a sharp decline of the EU development index values, reflecting the impact of global economic crisis, while some countries with a high level of public debt and low confidence of the financial markets have remained in their positions by the both indexes in the year 2009. However, these countries most probably will be forced to make the considerable fiscal discipline measures, which inevitably will have an impact on GDP and income indicators in these countries, therefore their rankings in the coming years will deteriorate. Completely impartial assessment will be possible when countries with high debt levels will have balanced their budgets and economic growth will be based mostly on their own income and production instead of external cash flows and investment entering the country. It can be concluded that EU Development Index allows, in a more equitable fashion, to assess disparities of the EU Member States by development level and more rapidly reflect the rapid socio-economic change.
\end{abstract}

Key words: Indicators, index, development.

\section{Introduction}

At the international level a number of different indexes have been developed, using in their formation various aspects of sustainable development and quality of life, such as level of education, life expectancy, GDP per capita, environmental damage, etc. Well-known in academic and policy-making environment is Human Development Index (HDI), which is regularly calculated for each country by the United Nations Organization. It allows assessing the public education and health care system of every state included in the calculation of the HDI, as well as income that can provide decent living conditions. The Human Development Index was developed in the sixties of the last century because the World Bank and a number of scientists came to the conclusion that per capita GDP can not be regarded as an exclusive indicator for evaluation of development. Justification for this view was that the GDP indicator is too multi-dimensional and does not include the distribution of welfare among members of society.
Moreover, GDP and income levels by themselves do not ensure the wider community objectives. The view that the GDP indicator is not sufficient for an evaluation of human development and progress is also expressed in the so-called Stiglitz Commission report (Commission on the Measurement ..., 2009). A similar opinion is expressed by Daly (1991), indicating that growth cannot be infinite and it is not even desirable, given the limited natural resources.

Cypher and Dietz (1997) also believe that the HDI is not a perfect indicator of the nation's wealth, as its averages are unable to provide an idea of the variations by region, gender, income groups and ethnic characteristics. Shortcomings of the HDI are recognized also by Latvian researcher Lavrinenko (2010), indicating that the HDI does not show how results of economic development are distributed.

In the context of the global financial-economic crisis which has questioned a sustainability of development in a number of countries it becomes

\footnotetext{
* Author's email: 
important to find a stronger base for the assessment of socio-economic development and, in particular, for better indicators. Selman (1999) points out that the indicators need to be able to monitor the transformation process of the development factors and elements and justify the necessary corrective measures. Organization for Economic Cooperation and Development indicates that the indicators have to be politically significant, analytically impeccable and measurable. From the political significance point of view, such indicators should be clearly defined, simple and easy to understand, internationally comparable, they must be linked to society's values and beliefs of the desired value of the indicators (OECD, 2005).

In several EU Member States, socio-economic situation has deteriorated significantly, by declining GDP per capita and employment rates, which resulted in a significant impact on their budgets and their ability to finance their expenditure. Until now, an internal EU Development Index has not been developed, which would allow a more comprehensive and better assessment of the socio-economic development level of each EU Member State, while comparing them to each other. The objective of the article is to describe the EU Development Index calculation results and compare them with the Human Development Index values for each Member State of the EU. Thus, the hypothesis is proposed that it is necessary to develop the EU Development index, which would ensure a more effective and timely assessment of the ongoing socio-economic change in the EU.

\section{Materials and Methods}

The EU Development Index calculation includes the use of eight indicators, which, according to scientific literature and the most important EU policy documents, are used for development evaluation and are also available from database of the Eurostat for all EU Member States for the selected period from the year 2007 until the year 2009.

One of the key indicators at the EU Member State level is GDP per capita, as it represents the country's economic activity for the respective calendar year, as well as timeliness of indicator values at EU Member State level is sufficient enough. Given the large disparities of the GDP per capita value between EU Member States, it serves as a major socio-economic development level indicator.

An important indicator that describes the effectiveness of the national economy is the labour productivity per person employed as a percentage of the EU-27 average. This indicator indirectly reflects the degree of economic modernization, the role of innovation in the economy, the progress made in introduction of new and more productive technologies that reduce production costs, thus higher labour productivity is considered to be a significant factor of competitiveness.

Substantial part of economic growth is the investments being made to increase production capacity by various equipment and other capital purchases. For characterization of this contribution, the Eurostat compiles the information necessary to calculate such indicator as gross fixed capital formation (investment) as a share of GDP. This parameter characterizes the country's economic potential and the intensity of its use, taking into account the potential return on investment opportunities, as well as indirectly the macroeconomic stability and confidence of residents in the country's future.

An important indicator of socio-economic development dynamics is population change during the calendar year (increases or decreases broken down for every 1000 inhabitants), which shows attractiveness of each individual country as a potential place of living and working from the point of view of potential immigrants. This indicator is particularly important in the light of fact that there are no restrictions in the EU for capital, goods and people flows, as well as labour markets in many EU-15 Member States are gradually opening to job seekers from the new EU Member States.

Employment has a significant impact on socioeconomic development. When an employment rate (the proportion of employees in the 15-64-year-old population) grows, it usually causes also an increase in GDP both in absolute amounts and per capita. Importance of this indicator is highlighted by the new EU strategy "Europe 2020", with inclusive development as one of its three main priorities (European Commission, 2010). In addition, increasing employment rate improves the social climate within society, because members of the public belonging to social exclusion risk groups are better integrated in the labour market, which in turn reduces crime, alcoholism, drug abuse and other negative social phenomena.

Today, in the modern economy, capability to generate new ideas and new solutions and to develop new products and services has become most important. This capability is based on a qualitative education, especially higher education, and therefore as one of the EU Development Index indicators 
30-34-year-old population with tertiary education as a share of all 30-34-year-old population was selected.

For the characterization of income levels in the EU Member States and for their mutual comparison, an average per capita income adjusted for purchasing power parity is an important indicator, which allows an impartial comparison of income levels across the countries and, thus, assessment of the levels of their socio-economic development. However, the average income level in the country only partially provides evidence on socio-economic development and, in particular, on the balance between development and social justice. Therefore, as one of the most important socio-economic development index indicators, Gini coefficient was used to include characteristics of income inequality. Strong emphasis on income inequality was put by Wilkinson and Pickett (2010) who, using data on EU Member States and the United States, demonstrated in their work "The Spirit Level" the negative impacts of income inequality on a number of social aspects, such as crime, mortality, teenage pregnancy, the incidence of mental illness, obesity, etc. Similar opinions were expressed also by a number of other researchers such as Donnellan (2004), Kawachi, Kennedy, Lochner, and Prothrow-Stith (1997), Martin (2000), Frank (2007), etc.

Within a framework of this article, standardization method applied for calculations of the Latvian Territorial Development Index was also used for comparison of socio-economic development levels of the EU Member States while calculating the EU Development Index values and respective rankings for each EU Member State in the years 2007, 2008 and 2009 and comparing obtained rankings for each EU Member State with those obtained by use of values of the Human Development Index. Values of the all above mentioned indicators for each of the EU Member States are fully available for the period from the year 2007 until 2009 from the database of the Eurostat.

The EU Development Index calculation was done by using the standardization method, which allows indicator values to be converted to standardized values. Standardized values of indicators were calculated as follows: firstly, difference between the absolute value of the indicator in a planning region and the arithmetic mean was calculated, and, secondly, the obtained difference was divided by standard deviation, using Formula 1 (Valsts reǵionālās ..., 2011):

$$
t=\frac{x-\bar{x}}{s}
$$

where

$t$ - standardized value of the indicator for the respective planning region;

$x$ - absolute value of the indicator for the respective planning region;

$\bar{x}-$ arithmetical mean of all values of the respective indicator;

$s$ - standard deviation of the respective indicator.

Summing the standardized values of all indicators, the EU Development Index value was obtained for each country, the size of which allows describing the country's socio-economic development and comparing it to other EU Member States.

To ensure an impartial assessment of the socioeconomic development level, it is necessary to give an adequate significance weight for each of the indicators included in the index because they characterize various aspects of the socio-economic development. This task was carried out with the help of an expert survey, asking the experts to assess the significance of each indicator for assessment of the EU Member States' socio-economic development level. The EU Development Index value calculations were made for the years 2007, 2008 and 2009. The calculated index values were used to create a ranking list of the EU Member States based on the principle that as higher socio-economic development index value is calculated for a specific country, the higher its rank in a ranking list. Rankings were assigned to each EU Member State according to the calculated EU Development Index values. These rankings were compared with those rankings of the EU Member States which were calculated using the HDI values for years 2007, 2008 and 2009.

\section{Results}

In total, thirty-eight respondents completed the questionnaire, of these twenty six were Ph.D.'s of economic science, and the other twelve hold master's degree in economic science. The calculated significance weights of indicators to be included into the EU Development Index calculation are shown in Figure 1. GDP per capita was assumed to be the most important indicator of socio-economic development by the questionnaire respondents, but labour productivity indicator was identified as the 


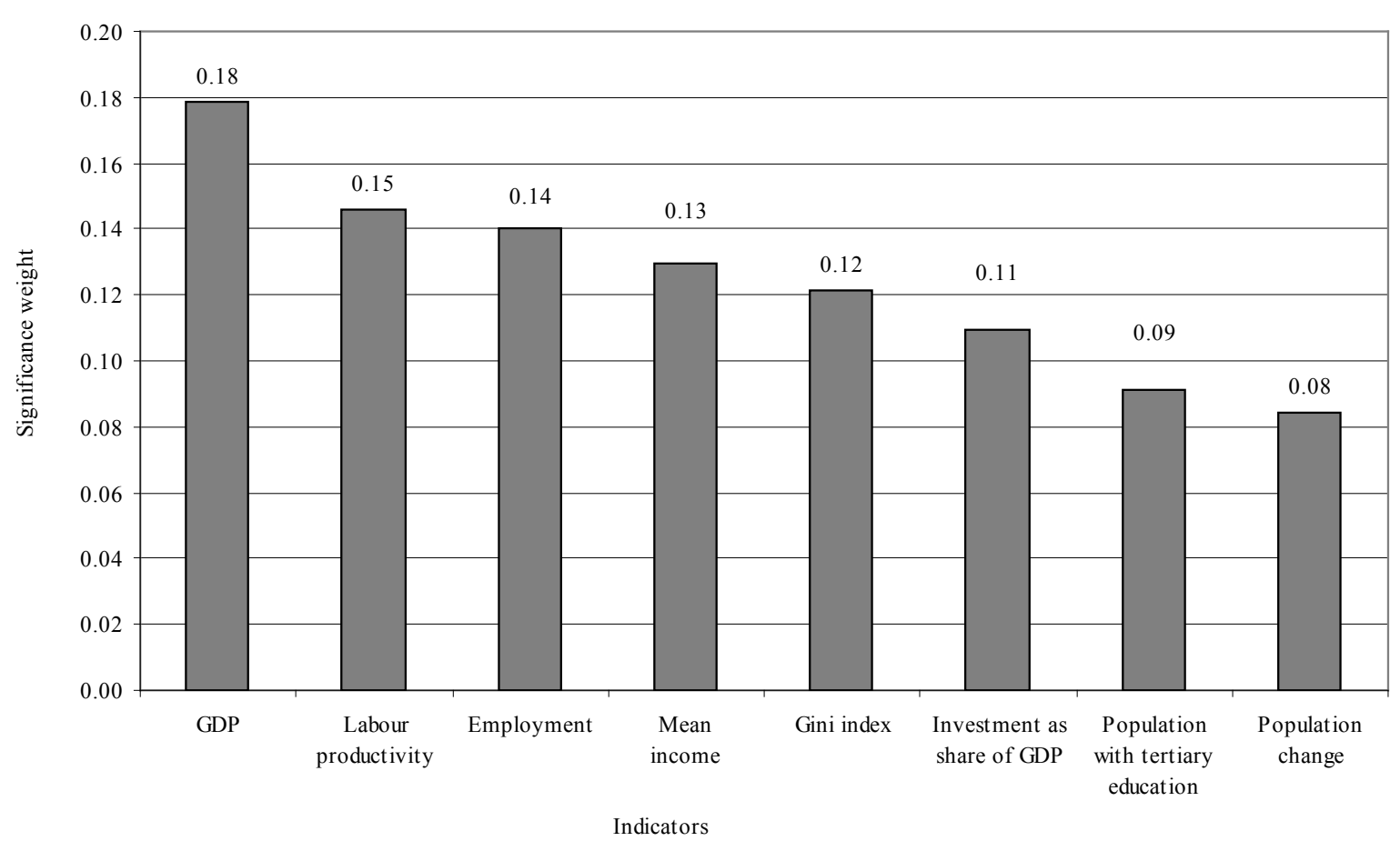

Fig. 1. Significance weights of indicators of the EU Development Index.

second most important. Both of these indicators are interrelated, since both point to the newly generated value in the country, but the important difference is that the first of them shows how much value is produced per inhabitant and characterizes overall well-being, regardless of age and participation in the labour market; on the other hand, the labour productivity indicator describes the amount of value produced per person employed and efficiency of use of the resources. Together these two factors determine one-third of the EU Development Index value.

A number of respondents indicated that GDP per capita is undoubtedly the basic indicator to be used to assess the level of economic development. However, some experts suggested that labour productivity is a major real driving force of the development, while some experts expressed the view that labour productivity growth can cause adverse social consequences - rising unemployment and other adverse social processes resulting from the unemployment.

Expert assessment set the Gini index as an important indicator, which shows that, according to respondents, not only the creation of economic benefits is important but also socially fair distribution of the produced value. A number of experts indicated that this indicator does not allow assigning of higher rankings to those countries where there is segregation of society and poverty, and also pointed that a high average income becomes almost irrelevant if there are high levels of income inequality. The author of the present research shares such conclusions on the high importance of this indicator and would like to stress also that people with low incomes cannot secure for themselves and their children good health care and education, which is the determining factor for an individual's future opportunities and competitiveness in the labour market and full inclusion in society.

A slightly lower importance weight has been assigned to investment or gross fixed capital formation indicator, as some experts believe that this indicator is not significant enough and is less important to assess the actual level of development, but is rather more focused on the future development and future development potential.

The second lowest rating was assigned to the share of population with tertiary education indicator, for which expert opinions varied substantially. Several experts suggested that even more important would be to list the people who possess the professional and/or higher education, as there are many people with higher education who do not have experience in industry practice. The lowest weight of the significance by assessment of the respondents was assigned to population change. Some respondents indicated that GDP per capita may rise and drop because of population change and that this indicator because of its complex content does not reflect the 
causes of the change, such as fertility or mortality levels.

The following part of the article represents EU Development Index calculation results, as well as their interpretation is given. EU Development Index was calculated using data on the values of the abovementioned eight indicators for the period from the year 2007 until year 2009. The EU Development Index values for each EU Member State and their respective rankings are listed in Table 1.

Among the EU-15 or so-called "old" EU Member States, Luxembourg should especially be noted - according to the EU Development Index it is significantly ahead of the Ireland which is ranked second. However, it is important to mention that for the Luxembourg the index value has significantly increased because of the GDP per capita figure which constitutes artefact, as the standardized indicator value for Luxembourg was 6.85. High GDP per capita in Luxembourg is due to the fact that it is a small country with a large foreign population among employees, which significantly increases the volume of GDP in absolute values, but it is associated to residents of Luxembourg. Germany, which has one of the major EU economies, is only at fourteenth place in the ranking list. This is mainly due to a negative population change, a lower gross fixed capital formation (investment) as the share of GDP, and a lower proportion of the population with a tertiary education. Among the EU-15 Member

Table 1

Values of the EU Development Index (EUDI) for EU Member States and respective rankings

\begin{tabular}{|c|c|c|c|c|c|c|}
\hline \multirow[b]{2}{*}{ Member State } & \multicolumn{2}{|c|}{2007} & \multicolumn{2}{|c|}{2008} & \multicolumn{2}{|c|}{2009} \\
\hline & $\begin{array}{l}\text { Value of } \\
\text { the EUDI }\end{array}$ & Ranking & $\begin{array}{l}\text { Value of } \\
\text { the EUDI }\end{array}$ & Ranking & $\begin{array}{l}\text { Value of } \\
\text { the EUDI }\end{array}$ & Ranking \\
\hline Luxembourg & 2.374 & 1 & 2.585 & 1 & 2.636 & 1 \\
\hline Ireland & 1.240 & 2 & 0.900 & 5 & 0.562 & 8 \\
\hline Sweden & 0.877 & 3 & 0.932 & 4 & 0.930 & 3 \\
\hline Denmark & 0.870 & 4 & 0.948 & 3 & 0.794 & 4 \\
\hline Netherlands & 0.799 & 5 & 0.967 & 2 & 1.015 & 2 \\
\hline Finland & 0.674 & 6 & 0.729 & 6 & 0.702 & 7 \\
\hline Austria & 0.576 & 7 & 0.656 & 7 & 0.743 & 5 \\
\hline Belgium & 0.559 & 8 & 0.579 & 8 & 0.742 & 6 \\
\hline Spain & 0.531 & 9 & 0.381 & 12 & 0.117 & 14 \\
\hline France & 0.449 & 10 & 0.439 & 11 & 0.504 & 10 \\
\hline Cyprus & 0.444 & 11 & 0.542 & 9 & 0.543 & 9 \\
\hline United Kingdom & 0.417 & 12 & 0.316 & 13 & 0.289 & 12 \\
\hline Slovenia & 0.315 & 13 & 0.462 & 10 & 0.419 & 11 \\
\hline Germany & 0.190 & 14 & 0.199 & 14 & 0.274 & 13 \\
\hline Italy & -0.179 & 15 & -0.148 & 15 & -0.174 & 15 \\
\hline Czech Republic & -0.253 & 16 & -0.218 & 16 & -0.213 & 16 \\
\hline Estonia & -0.333 & 17 & -0.432 & 18 & -0.727 & 19 \\
\hline Greece & -0.419 & 18 & -0.424 & 17 & -0.405 & 17 \\
\hline Malta & -0.428 & 19 & -0.534 & 20 & -0.732 & 20 \\
\hline Slovakia & -0.572 & 20 & -0.465 & 19 & -0.503 & 18 \\
\hline Portugal & -0.691 & 21 & -0.718 & 21 & -0.745 & 21 \\
\hline Lithuania & -0.774 & 22 & -0.882 & 23 & -1.369 & 25 \\
\hline Latvia & -0.781 & 23 & -1.018 & 24 & -1.423 & 26 \\
\hline Hungary & -0.887 & 24 & -0.861 & 22 & -0.784 & 22 \\
\hline Poland & -1.144 & 25 & -1.056 & 25 & -0.892 & 23 \\
\hline Bulgaria & -1.348 & 26 & -1.201 & 26 & -1.171 & 24 \\
\hline Romania & -1.501 & 27 & -1.397 & 27 & -1.443 & 27 \\
\hline
\end{tabular}

Source: Eurostat, 2010, 2011. 
States, Italy, Portugal and Greece have the lowest EU Development Index values, and Portugal and Greece have already been forced to turn to the EU and the IMF for a loan to stabilize their financial situation. However, it is important to note that their financial problems escalated in 2010 and later, which to a large extent explains the fact that during the period from 2007 to 2009 their ranking position in the list remained stable.

Ten EU Member States with the lowest EU Development Index values are mostly EU-12 Member States but also include two EU-15 Member States, namely Portugal and Greece.

The EU Development Index value of Portugal in 2007 was mostly affected by the high value of the Gini index and the low labour productivity, but for Greece - by the high value of the Gini index and the low employment rate. For the Baltic countries, GDP per capita and labour productivity ratio had the greatest impact on the EU Development Index value, especially in the case of Latvia where the positive indicators were only the gross fixed capital formation (investment) as a share of GDP and the employment. It should be noted that in 2007, all three Baltic countries had a positive value of gross fixed capital formation (investment) as a share of the GDP indicator; in addition, Estonia and Latvia were the two most successful EU Member States in this respect.

Taking into account that selected period includes the year 2007, which is a time before the global financial economic crisis, and the years 2008 and 2009, which marked the beginning of the crisis and the subsequent impact on socio-economic development of the EU Member States, it is important to analyze dynamics of the newly established EU development index values for the EU Member States within these three years.

While assessing changes in the EU Development Index value in the EU-15 Member States, it can be concluded that during the period 2007-2009 these countries, with the exception of Ireland, were not substantially affected by the global financial economic crisis. For Ireland, the highest index value decrease was caused by a sharp decrease in population and an employment decline, as well as a substantial decrease in GDP per capita; however, it should be noted that the Gini index value during this period decreased, thus decreasing also the income inequality. Sharp decrease in the EU Development Index value was also observed in Spain, where the index value declined more than four times. This significant decline was mainly caused by decrease in the population, in the gross fixed capital formation (investment) as the share of GDP, and in the employment rate, as well as by increase in the income inequality. On the other hand, some Member States have increased their EU Development Index values during the global economic crisis. For example, Belgium, despite the problems to form active government and rather high internal debt, performed rather well during the reference period and increased its EU Development Index value from 0.579 up to 0.742 , because of the positive population change and decrease in Gini index as well as because of the maintained level of investment as a share of GDP. Similar trends are observed for the Netherlands where the positive rate of population change and the growth of GDP were actually the main contributors to the increase in the EU Development Index value.

Looking at the change in the EU Development Index of the EU-12 Member States during the relevant period, it appears that several of them have improved their position in the ranking list. In 2009, Cyprus, Slovenia, Slovakia, Hungary, Bulgaria and Poland improved their positions in the ranking list for two positions, compared to the data for 2009 and 2007. However, it is noted that index values for Slovenia and Slovakia in 2009 against the value of the index values of the 2008 have declined. Whereas for the Baltic States the value of the EU Development Index in 2009 has decreased approximately two times; subsequently, Latvia and Lithuania dropped down three positions and Estonia two positions in the ranking list, which is not surprising, given that the global financial economic crisis has had a particularly heavy impact in the Baltic countries. In the case of Latvia, the greatest negative impact on the value of the EU Development Index resulted from a sharp decrease in the gross fixed capital formation (investment) as a share of GDP, employment levels have also decreased and income inequality increased, similar processes have also taken place in Lithuania and Estonia. The overall conclusion is that the EU index value calculation results objectively reflect the significant socio-economic development gaps among the "old" and "new" EU member states. However, it should be noted that several of the "new" EU countries have high positions in the ranking list of the EU Development Index and demonstrate sustainable development, for example, Cyprus and Slovenia.

It is important to point out that the most significant factor influencing the index values of the EU Member States was the gross fixed capital formation (investment) as a share of GDP and 
employment and, in some cases, also population change and income inequality. With decline in the investment flows in several EU Member States, they have also experienced decreasing employment rates, which, in turn, resulted in decreasing GDP per capita and median income. The above-mentioned indicates that the Member States should focus more on how to implement sustainable growth policies without sectorally unbalanced and excessively rapid inflow of investment in the economy.
Further, a comparison is made between the rankings of the EU Member States by EU Development Index values and the respective rankings of the EU Member States arranged on the basis of the Human Development Index values for EU Member States. Rankings of the EU Member States by the EU Development Index and rankings by Human Development Index are arranged in Table 2 demonstrating that similar to the case in the EU Development Index, clearly marked significant

Table 2

Ranking of the EU Member States by the values of the EU Development Index (EUDI) and Human Development Index (HDI)

\begin{tabular}{|c|c|c|c|c|c|c|}
\hline \multirow[b]{2}{*}{ Member State } & \multicolumn{2}{|c|}{2007} & \multicolumn{2}{|c|}{2008} & \multicolumn{2}{|c|}{2009} \\
\hline & $\begin{array}{c}\text { EUDI } \\
\text { ranking }\end{array}$ & $\begin{array}{c}\text { HDI } \\
\text { ranking }\end{array}$ & $\begin{array}{c}\text { EUDI } \\
\text { ranking }\end{array}$ & $\begin{array}{c}\text { HDI } \\
\text { ranking }\end{array}$ & $\begin{array}{c}\text { EUDI } \\
\text { ranking }\end{array}$ & $\begin{array}{c}\text { HDI } \\
\text { ranking }\end{array}$ \\
\hline Ireland & 2 & 1 & 5 & 1 & 8 & 1 \\
\hline Netherlands & 5 & 2 & 2 & 2 & 2 & 2 \\
\hline Sweden & 3 & 3 & 4 & 3 & 3 & 3 \\
\hline Germany & 14 & 4 & 14 & 4 & 13 & 4 \\
\hline Finland & 6 & 5 & 6 & 5 & 7 & 5 \\
\hline Denmark & 4 & 6 & 3 & 7 & 4 & 8 \\
\hline Belgium & 8 & 7 & 8 & 8 & 6 & 7 \\
\hline France & 10 & 8 & 11 & 6 & 10 & 6 \\
\hline Luxembourg & 1 & 9 & 1 & 10 & 1 & 12 \\
\hline Spain & 9 & 10 & 12 & 9 & 14 & 9 \\
\hline Italy & 15 & 11 & 15 & 12 & 15 & 11 \\
\hline Greece & 18 & 12 & 17 & 11 & 17 & 10 \\
\hline Austria & 7 & 13 & 7 & 13 & 5 & 13 \\
\hline United Kingdom & 12 & 14 & 13 & 14 & 12 & 14 \\
\hline Czech Republic & 16 & 15 & 16 & 15 & 16 & 15 \\
\hline Slovenia & 13 & 16 & 10 & 16 & 11 & 16 \\
\hline Estonia & 17 & 17 & 18 & 17 & 19 & 19 \\
\hline Slovakia & 20 & 18 & 19 & 18 & 18 & 17 \\
\hline Malta & 19 & 19 & 20 & 19 & 20 & 18 \\
\hline Cyprus & 11 & 20 & 11 & 20 & 9 & 20 \\
\hline Hungary & 24 & 21 & 22 & 21 & 22 & 21 \\
\hline Portugal & 21 & 23 & 21 & 23 & 21 & 22 \\
\hline Lithuania & 22 & 22 & 23 & 22 & 25 & 24 \\
\hline Poland & 25 & 24 & 25 & 24 & 23 & 23 \\
\hline Latvia & 23 & 25 & 24 & 25 & 26 & 25 \\
\hline Romania & 27 & 26 & 27 & 26 & 27 & 26 \\
\hline Bulgaria & 26 & 27 & 26 & 27 & 24 & 27 \\
\hline
\end{tabular}

Source: United Nations ..., 2010. 
differences exist between the EU-15 or "old" EU Member States and the EU-12 or "new" EU Member States. The 14 top positions in the HDI ranking list are taken by "old" EU Member States, and Portugal is only one of the "old" EU Member States whose ranking is significantly lower, allowing a number of "new" EU Member States to be ahead of it. On the other hand, the "new" EU Member States are found in the bottom of the ranking list, and their rankings, with few exceptions, differ a little from the layout of the EU Development Index values. The most substantial differences in the rankings, when evaluating the EU-12 Member States, are visible for Cyprus and Slovenia, as they both indicate a higher level of development by the EU Development Index than by the Human Development Index. Comparison of the EU-15 rankings shows that Luxembourg and Germany have significant differences between both indexes.

\section{Discussion}

Comparing the EU development index and The Human Development index value changes for each EU member state, several fundamental differences are seen between the both indexes. Firstly, the ranking list of the EU member states arranged according to Human Development Index values has not changed substantially (fourteen out of twenty-seven countries remained unaltered in their rankings all three reporting years), which shows a degree of inflexibility and the lack of response of the Human Development Index to major socio-environmental changes that occurred during the global financial economic crisis. It should also be noted that a comparison of both indexes allows one to detect some contradictions. Ireland maintained the first position in the HDI ranking list in 2008 and 2009, but it dropped down from first position in 2007 in the EU Development Index ranking list to only eighth in 2009; similar trends are observed also for Spain and Malta. Latvia maintained position No. 25 in the HDI ranking list, but in the EU Development Index ranking list has moved from position No. 23 down to position No. 26. This suggests that the EU Development Index better reflects the socio-economic development level during rapid socio-economic changes. In the Irish and Latvian case, the global financial economic crisis has strongly manifested itself since the very early stage, which is also confirmed by the decrease in the EU Development Index values and rankings.

At the same time it is necessary to point to the fact that Greece has improved its position in the ranking lists of both indexes, while the positions of Portugal have remained unchanged. This confirms large differences in the actions of these EU Member States and different time moments of the escalation of problems, as well as different approaches in the selection of crisis solutions. The different time moments of crisis and different government reactions allow an objective comparison between the current levels of development for the current year but only partially allow predicting the changes in the longer run.

Financial crisis of the Euro zone in 2010 and 2011, with the Greek and Portuguese financial difficulties in the centre, and high public debt levels in other euro area countries, means that a number of countries will be forced to make the large fiscal discipline measures, which inevitably will have an impact on GDP and income indicators in these countries, therefore their ranks in the coming years will decrease. Completely objective assessment will be possible at the moment when countries with high debt levels will have managed to balance their budgets and their economic growth will be based essentially on their own income, instead of external cash flows and investment. The overall conclusion is that the EU Development Index allows better assessment of the socio-economic development level of the EU Member States, because with a wider range of indicators it is possible to more rapidly identify the economic dynamics and changes in the socio-economic development level and quality of life.

\section{Conclusions}

1. The new EU Development Index includes a wider set of socio-economic indicators, which allows a more detailed evaluation of the development trends in the EU Member States and of the impact of socio-economic processes on the level of development of the EU Member States.

2. The EU Development Index calculation results show a correlation between the investment as share of GDP indicator, on the one hand, and the employment and GDP per capita, on the other hand, because in those countries where the crisis has sharply reduced investment flows, employment and GDP per capita also fell sharply.

3. It is essential to ensure the priority for productive investment inflows, which are aimed at increasing the labour productivity and the share of high value added goods and services as well as at strengthening the exporting capacity of companies, thus ensuring raising of 
competitiveness of the State and the enterprises as well as their resilience to changes in the global economic environment.

\section{References}

1. Commission on the Measurement of Economic Performance and Social Progress. (2009). Report by the Commission on the Measurement of Economic Performance and Social Progress. Retrieved from http://www.stiglitz-sen-fitoussi. fr/documents/rapport_anglais.pdf

2. Cypher, J.M., \& Dietz, J.L. (1997). The Process of Economic Development. London, New York: Routledge.

3. Daly, H. (1991). Steady-state Economics. Washington, DC: Island Press.

4. Donnellan, C. (2004). Mental Wellbeing. Cambridge: Independence Educational Publishers.

5. Frank, R.H. (2007). Falling Behind: How Rising Inequality Harms the Middle Class. Berkeley, CA: University of California Press.

6. European Commission. (2010). A Strategy for Smart, Sustainable and Inclusive growth. Communication from the Commission to the European Parliament and the Council. Retrieved from http://eur-lex.Europa.eu/LexUriServ/Lex UriServ.do?uri=COM:2010:2020:FIN:EN:PDF.

7. Eurostat. (2010). Europe in figures - Eurostat yearbook 2010. Luxembourg: Office for official publications of the European Communities.
8. Eurostat. (2011). Europe in figures - Eurostat yearbook 2011. Luxembourg: Office for official publications of the European Communities.

9. Kawachi, I., Kennedy, B.P., Lochner, K., \& Prothrow-Stith, D. (1997). Social capital, income inequality and mortality. American Journal of Public Health, 87(9), 1491-1498.

10. Lavriṇenko, O. (2010). Centrāleiropas un Austrumeiropas iedzīvotāju dzīves līmeņa veidošanās atšksirību pētī̌sana pa regioniem. Rēzekne: Latgales kultūras centra izdevniecība.

11. Martin, B. (2000). Income inequality in Germany during the 1980s and 1990s. Review of Income and Wealth, 46(1), 1-19.

12. OECD. (2005). Handbook on Constructing Composite Indicators: Methodology and User Guide. Paris: OECD.

13. Selman, P. (1999). Three decades of environmental planning: What have we really learned? In M. Kenny \& J. Meadowcroft (Eds.), Planning Sustainability (pp. 148-174). London: Routledge.

14. United Nations development Programme. (2010). Human development report 2010. Retrieved from http://hdr.undp.org/en/media/ HDR_2010_EN_Table1_reprint.pdf

15. Valsts reǵionālās attīstības aǵentūra. (2011). Regionu attīstība Latvijā 2010. Rīga: Valsts reǵionālās attīstības aǵentūra.

16. Wilkinson, R., \& Pickett, K. (2010). The Spirit Level. London: Penguin books.

\section{Acknowledgements}

The author gratefully acknowledges the funding from the European Union and the European Social Fund (Agreement No. 2009/0180/1DP/1.1.2.1.2/09/IPIA/VIAA/017 „, Support for Doctoral Studies Programme of Latvia University of Agriculture”, contract No. 04.4-08/EF2.PD.35). 